\title{
PENGARUH OKULASI BERTINGKAT TERHADAP PERTUMBUHAN BIBIT KARET (Hevea brasiliensis Muell Arg.) ASAL STEK
}

\author{
Effect of Gradual Grafting to Growth of Rubber (Hevea brasiliensis Muell Arg.) \\ Planting Material from Cutting \\ Lestari ADMOJO* dan Nur Eko PRASETYO \\ Balai Penelitian Getas, Pusat Penelitian Karet \\ Jalan Pattimura KM 6 PO BOX 804 \\ Salatiga 50702 Jawa Tengah \\ *Email : tariadmojo@gmail.com
}

Diterima : 29 Mei 2019 / Disetujui : 18 Juni 2019

\begin{abstract}
The problem of rootstock availability could be overcomed with cutting of budded rootstock. This research aimed to know the response of shoot and root growth of plant that issued from $2^{\text {nd }}$ and $3^{\text {rd }}$ grafting compared to $1^{\text {st }}$ grafting in a same rootstock. The study was conducted by grafting three levels of stem of rootstock (>7 month old), which namely $1^{\text {st }}, 2^{\text {nd }}$, and $3^{\text {rd }}$, with a spacing between about $20 \mathrm{~cm}$. After the grafting was successful, that of budded stem sections were separated then cutting made on plastic cup. Variables that observed were stem color, grafting succes percentage, time of bud break, cutting mortality rate, root and shoot growth. The results showed that the success rate of grafting was $80 \%$ for $1^{\text {st }}$ grafting, $84 \%$ for $2^{\text {nd }}$ grafting and $71 \%$ for $3^{\text {rd }}$ grafting. Range time of bud break was at 11 - 19 day after cutting (DAC). The average height of shoot in 49 DAC for the $2^{\text {nd }}$ and $3^{\text {rd }}$ grafting were $7.55 \mathrm{~cm}$ and $7.66 \mathrm{~cm}$ respectively and percentage of rooting were $69 \%$ and $52 \%$ respectively, with an average root length of $4.80 \mathrm{~cm}$ and 3.23 $\mathrm{cm}$, both of which were significantly lower than the $1^{\text {st }}$ grafting (control), $18.05 \mathrm{~cm}$ for shoot height and $14.7 \mathrm{~cm}$ for root length.
\end{abstract}

Keywords: Clonal material; cutting; grafting; rootstock; rubber plant

\begin{abstract}
Abstrak
Permasalahan ketersediaan batang bawah dapat diatasi melalui stek batang bawah yang telah diokulasi. Tujuan penelitian ini untuk melihat respon pertumbuhan tunas dan perakaran hasil okulasi kedua dan ketiga dibandingkan
\end{abstract}

dengan okulasi pertama pada batang bawah yang sama. Penelitian dilakukan dengan mengokulasi batang bawah usia 7 bulan sebanyak tiga tingkat, yaitu okulasi pertama, okulasi kedua dan okulasi ketiga dengan jarak antar okulasi sekitar $20 \mathrm{~cm}$. Setelah okulasi berhasil, tanaman dipotong dan distek dalam root trainer. Pengamatan meliputi diameter dan warna kulit batang, tingkat keberhasilan okulasi, waktu pecah tunas, tingkat kematian stek, pertumbuhan akar, dan tunas setelah distek. Hasil penelitian menunjukkan tingkat keberhasilan okulasi masing-masing sebesar $80 \%$ untuk okulasi pertama, 84\% untuk okulasi kedua, dan $71 \%$ untuk okulasi ketiga. Waktu optimal pecah tunas pada 11-19 HSS. Rata-rata tinggi tunas okulasi umur 49 HSS untuk okulasi kedua dan ketiga masing-masing sebesar 7,55 cm dan $7,66 \mathrm{~cm}$ dan persentase berakar masing-masing sebesar $69 \%$ dan 52\%, dengan rata-rata panjang akar 4,80 $\mathrm{cm}$ dan $3,23 \mathrm{~cm}$, keduanya nyata lebih rendah dari kontrol sebesar $18,05 \mathrm{~cm}$ untuk tinggi tunas dan 14,7 cm untuk panjang akar.

Kata kunci: Batang bawah; bibit klonal; okulasi; stek; tanaman karet

\section{PENDAHULUAN}

Ketersediaan batang bawah seringkali terkendala ketersediaan biji. Faktor yang mempengaruhi kurang tersedianya biji untuk batang bawah salah satunya yaitu pola iklim yang tidak menentu. Hal tersebut menyebabkan produksi biji dari tanaman karet tidak optimal atau bahkan tidak menghasilkan biji 
sama sekali. Ketika biji harus diambil dari lokasi yang jauh, antar pulau misalnya, seringkali memiliki viabilitas dan daya kecambah yang sangat rendah. Ketersediaan biji tersebut sangat mempengaruhi ketersediaan batang bawah untuk produksi bahan tanam karet. Upaya untuk mengatasi ketersediaan batang bawah tersebut bisa dilakukan melalui stek batang bawah.

Stek batang bawah tanaman karet telah banyak dilakukan sejak tahun 1870 (Baulkwill \& Webster, 1989), sekalipun hingga saat ini belum pada tahap perbanyakan untuk kepentingan komersial. Rubber Research Institute of Malaysia (RRIM) melaporkan bahwa sekalipun tidak memiliki akar tunggang sejati melainkan berupa akar tunggang semu (pseudo taproot), tanaman karet yang berasal dari bibit dengan batang bawah asal stek mampu bertahan dari serangan angin, di samping mencapai lilit batang dan persentase matang sadap yang tidak jauh berbeda dengan bibit okulasi (Baulkwill \& Webster, 1989). Hasil penelitian Antwi-Wiredu et al. (2018) menunjukkan hanya stek dari batang bawah yang berwarna cokelat yang berhasil hidup di lapangan. Hasil pengujian lain menunjukkan stek batang bawah memungkinkan menghasilkan tanaman dengan perakaran yang mampu mendukung pertumbuhan batang atas (Corpuz, 2013). Stek mikro untuk menghasilkan batang bawah klonal di laboratorium juga sudah dilakukan, hanya masih dianggap belum ekonomis untuk digunakan skala massal. Stek batang bawah tanaman karet memang bisa dilakukan, namun batang bawah asal stek tersebut setidaknya membutuhkan waktu antara $5-8$ bulan untuk memulihkan tebal kulit agar siap dan layak diokulasi. Upaya untuk menghilangkan rentang waktu tersebut dapat dilakukan dengan mengokulasi terlebih dahulu ruas batang bawah yang akan distek.

Okulasi konvensional batang bawah karet hanya dilakukan pada satu sayatan jendela okulasi yang posisinya $5 \mathrm{~cm}$ di atas permukaan media tanam. Jendela okulasi dalam satu tanaman batang bawah dapat dibuat lebih dari satu di atas jendela okulasi konvensional. Permasalahannya adalah ruas batang terokulasi dari jendela tambahan tersebut belum memiliki perakaran bila dijadikan bahan tanam.
Upaya pengakaran dapat dilakukan dengan stek. Tujuan penelitian ini yaitu mengetahui performa keragaan bahan tanam karet hasil okulasi pada jendela pertama, kedua, dan ketiga setelah distek dan ditanam dalam root trainer.

\section{BAHAN DAN METODE}

Penelitian dilaksanakan di kebun percobaan Balai Penelitian Getas pada bulan Maret hingga Agustus 2018. Bahan yang digunakan berupa batang bawah karet root trainer berumur tujuh bulan dari biji populasi klonal PB 260, batang atas klon IRR 118 , media tanam berupa top soil : cocopeat : pasir : sekam dengan perbandingan $3: 2: 1$ : 1, fungisida berbahan aktif benomil, zat pengatur tumbuh (ZPT) akar komersial berbahan aktif Indole Butyric Acid (IBA) dan Naphtalene Acetic Acid (NAA) dan parafin cair. Alat yang digunakan adalah gunting pangkas, root trainer, timbangan, perlengkapan okulasi, semprotan, gembor, ember, cangkul, meteran, timbangan, paranet, plastik sungkup, thermohigrometer, lux meter, dan jangka sorong.

Batang bawah diokulasi dengan tiga sayatan jendela okulasi. Masing-masing perlakuan dilakukan sebanyak 45 tanaman. Sayatan untuk jendela pertama dilakukan pada $5 \mathrm{~cm}$ dari permukaan media tanam. Okulasi pada jendela pertama merupakan okulasi konvensional dan sebagai perlakuan kontrol, selanjutnya disebut sebagai okulasi pertama. Sayatan jendela kedua dibuat pada $20 \mathrm{~cm}$ di atas jendela okulasi pertama. Perlakuan okulasi pada jendela kedua tersebut selanjutnya disebut sebagai okulasi kedua. Sayatan jendela ketiga dibuat pada $20 \mathrm{~cm}$ di atas jendela okulasi kedua. Perlakuan okulasi pada jendela ketiga tersebut selanjutnya disebut dengan okulasi ketiga (Gambar 1). Okulasi pertama dilakukan sekitar bulan Maret 2018. Setelah satu bulan pengecekan dan dipastikan okulasi berhasil, dilakukan okulasi kedua dibagian atas okulasi pertama. Setelah okulasi kedua dipastikan berhasil, dilakukan okulasi ketiga pada bagian atas okulasi kedua. Pengecekan okulasi dilakukan 21 hari setelah okulasi. Pada pengecekan dihitung berapa persentase keberhasilan okulasi dari masing-masing ruas tersebut. 
Satu bulan setelah pengecekan okulasi ketiga, dilakukan pemotongan terhadap ruas-ruas batang bawah untuk okulasi yang berhasil. Posisi pemotongan okulasi pertama yaitu sekitar $15 \mathrm{~cm}$ dari pertautan okulasi. Adapun panjang potongan ruas okulasi kedua dan ketiga masing-masing $20 \mathrm{~cm}$. Ruas okulasi kedua dan ketiga setelah dipotong selanjutnya direndam dalam larutan fungisida dengan konsentrasi $0,5 \mathrm{~g} / \mathrm{L}$ selama 24 jam. Selanjutnya dikeringanginkan dan dioles zat pengatur tumbuh (ZPT) penginduksi akar komersial (berbahan aktif NAA dan IBA) dengan konsentrasi $5 \mathrm{~g} / \mathrm{L}$ selama 5 menit. Seluruh media dan areal percobaan disemprot fungisida untuk mencegah serangan jamur. Selanjutnya ujung ruas dicelup parafin untuk mencegah penguapan dan serangan rayap. Ruas batang selanjutnya distek pada media tanam dalam gelas plastik. Stek ruas yang telah diokulasi tersebut kemudian disungkup plastik transparan individual dan diletakkan di dalam rumah kaca dengan intensitas naungan sebesar $75 \%$. Okulasi pertama selanjutnya dicabut (mengikutkan perakaran dengan bagian akar tunggang yang terpotong) dan dipindahkan untuk selanjutnya digunakan sebagai kontrol. Pemeliharaan yang dilakukan yaitu berupa penyiraman di sekeliling sungkup untuk menjaga suhu dan kelembaban. Selain itu juga penyemprotan fungisida ketika ada indikasi serangan jamur.
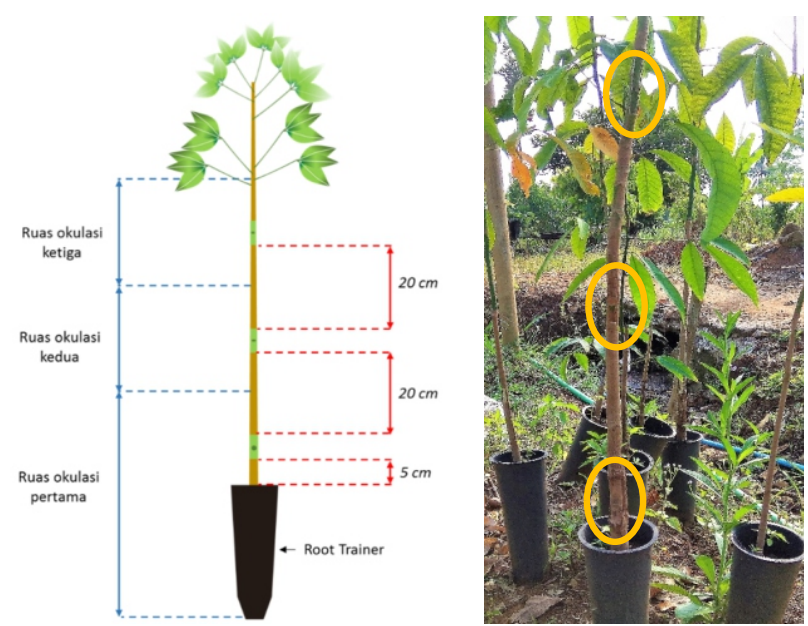

Gambar 1. Perlakuan okulasi pertama, kedua, dan ketiga pada batang bawah yang sama Figure 1. Treatment of $1^{\text {st }}, 2^{\text {nd }}$, and $3^{\text {rd }}$ grafting on the same of rubber rootstock

\section{Parameter Pengamatan}

Pengamatan dilakukan terhadap:

1. Diameter batang dan warna kulit batang pada area ruas yang diokulasi. Pengukuran dilakukan sebelum okulasi. Diameter batang diukur pada area okulasi menggunakan jangka sorong dan warna batang diamati secara visual.

2. Tingkat keberhasilan okulasi. Pengamatan dilakukan sebulan setelah okulasi. Persentase dihitung dari perbandingan okulasi hidup terhadap total tanaman terokulasi.
3. Pengamatan kondisi lingkungan tumbuh, waktu, dan persentase pecah tunas. Kondisi lingkungan tumbuh meliputi rata-rata suhu, kelembaban, dan intensitas cahaya yang diamati pada pagi dan siang hari. Waktu pecah tunas diamati setiap empat hari sekali dan persentase dihitung saat akhir pengamatan.

4. Tingkat kematian dan respon pertumbuhan tanaman yang meliputi tinggi tunas, panjang akar, rasio berat basah, dan berat kering akar dan tunas. Pengamatan panjang akar, berat basah, dan berat kering dilakukan pada 
tanaman sampel sebanyak lima tanaman tiap perlakuan. Tinggi tunas diamati setiap minggu sejak 21 hari setelah stek hingga hari ke-49.

\section{Analisis Data}

Data diameter batang, berat basah dan berat kering biomasa tanaman dianalisis menggunakan sidik ragam dari Rancangan Acak Lengkap (RAL) satu faktor yaitu faktor tingkat okulasi yang berbeda dan uji lanjut menggunakan uji Tukey untuk rerata data yang berbeda nyata.

\section{HASIL DAN PEMBAHASAN}

\section{Kondisi Umum dan Tingkat Keberhasilan Okulasi}

Hasil pengukuran suhu dan kelembaban harian rata-rata lokasi pengujian berkisar antara $22-24^{\circ} \mathrm{C}$ dengan tingkat kelembaban antara 56 - 68\% pada pagi hari. Pada siang hari kisaran suhu mencapai $30-36^{\circ} \mathrm{C}$ dan kelembaban mencapai 80 - 90\%. Intensitas naungan sekitar $75 \%$.

Data pada Tabel 1 menunjukkan adanya pengaruh ukuran diameter dan warna batang terhadap tingkat keberhasilan okulasi. Warna batang ruas okulasi pertama dan kedua yaitu cokelat dengan diameter rata-rata mencapai $13,63 \mathrm{~mm}$ dan 13,05 mm, keduanya tidak berbeda nyata. Hasil okulasi keduanya juga tidak jauh berbeda yaitu 84\% dan 80\%. Ruas okulasi ketiga berdiameter batang sekitar $11,70 \mathrm{~mm}$ dan rata-rata warna batangnya peralihan dari cokelat menuju hijau dengan tingkat keberhasilan okulasi yang lebih rendah yaitu $71 \%$.

Salah satu faktor yang mempengaruhi kegagalan okulasi adalah reaksi inkompatibilitas alami (natural incompatibility) antara spesies sebagai batang atas dan batang bawah atau disebut "incompatibility between partners". Beberapa faktor lain yang disebutkan oleh Goldschmidt (2014) dalam Baron et al. (2019) yaitu; patogen aktif dalam jaringan pembuluh floem, kondisi lingkungan yang kurang mendukung (suhu dan/atau kelembaban), dan ketidakmampuan menyatunya jaringan pembuluh dari kedua sambungan. Selain kompatibilitas antara batang bawah dan batang atasnya, selanjutnya adalah teknik, kesesuaian ukuran dan penyambungan yang benar, yang akan memicu penyatuan jaringan antara kedua bagian tanaman. Penyatuan jaringan yang berhasil akan menyebabkan terjadinya akspresi gen tertentu, tercegahnya akumulasi senyawa fenolik, dan terjadinya keseimbangan fitohormon hingga penyatuan jaringan paska penyambungan menjadi sempurna. Penyatuan jaringan yang sempurna akan mendukung translokasi hormon, nutrisi,

Tabel 1. Rata-rata diameter batang dan tingkat keberhasilan okulasi pada perlakuan okulasi yang berbeda

Table 1. Mean of stem diameter and grafting success on different grafting treatment

\begin{tabular}{cccc}
\hline $\begin{array}{c}\text { Perlakuan } \\
\text { Treatment }\end{array}$ & $\begin{array}{c}\text { Warna batang } \\
\text { Stem color }\end{array}$ & $\begin{array}{c}\text { Rata-rata } \\
\text { diameter batang } \\
\text { Mean of stem diameter } \\
(\mathrm{mm})\end{array}$ & $\begin{array}{c}\text { Keberhasilan } \\
\text { okulasi } \\
\text { Grafting } \\
\text { success } \\
(\%)\end{array}$ \\
\hline $\begin{array}{c}\text { Okulasi pertama } \\
\text { (kontrol) }\end{array}$ & Cokelat & $13,63^{\mathrm{a}}$ & 84 \\
Okulasi kedua & Cokelat & $13,63^{\mathrm{a}}$ & 80 \\
Okulasi ketiga & $\begin{array}{c}\text { Peralihan } \\
\text { cokelat/hijau }\end{array}$ & $11,70^{\mathrm{b}}$ & 71 \\
\hline
\end{tabular}

Keterangan (Remaks):

Angka yang diikuti dengan huruf yang sama pada kolom yang sama menunjukkan tidak berbeda nyata pada taraf signifikasi 5\% berdasarkan uji Tukey (Figures followed by the same letter at the same column were not significantly different at $5 \%$ based on Tukey test). 
dan karbohidrat yang selanjutnya menyebabkan pertumbuhan tanaman menjadi normal (Baron et al., 2019).

Diameter batang yang lebih kecil dan kondisi kulit masih hijau pada ruas okulasi ketiga, diduga menghasilkan kekurang sesuaian dengan kondisi entres yang digunakan. Kulit batang yang lebih lentur dan tipis (masih hijau) pada okulasi ketiga juga kemungkinan menyebabkan tenaga okulator kurang terbiasa menanganinya. Kondisi tersebut diduga menjadi faktor yang mempengaruhi rendahnya tingkat keberhasilan okulasi pada perlakuan okulasi ketiga.

Penyebab utama kematian tanaman adalah kekeringan pada batang yang selanjutnya diikuti serangan jamur. Faktor suhu dan kulit batang yang tipis dapat menjadi faktor utama yang menyebabkan kekeringan diikuti kematian tanaman. Kisaran suhu lingkungan rata-rata lebih tinggi dibandingkan dengan suhu optimal untuk pertumbuhan stek yaitu berkisar antara $21^{\circ} \mathrm{C}-30^{\circ} \mathrm{C}$, terutama menjelang siang yang mencapai $36^{\circ} \mathrm{C}$.

Owen Jr (2007) melaporkan bahwa pembelahan sel mencapai optimal pada kisaran suhu $35^{\circ} \mathrm{C}$, namun rerata maksimum pembelahan dan pemanjangan sel yang memicu inisiasi dan pertumbuhan akar terjadi pada kisaran suhu $30^{\circ} \mathrm{C}$. Kisaran suhu di atas $35^{\circ} \mathrm{C}$ dapat meningkatkan laju transpirasi dan mempercepat respirasi. Hal tersebut dapat menyebabkan tanaman kehilangan energi akibat penurunan cadangan makanan yang pada akhirnya dapat menyebabkan kematian tanaman (De Almeida et al., 2017).

Tabel 2. Jumlah tanaman mati, pecah tunas, dan persentase pecah tunas pada umur dua bulan setelah stek (BSS)

Table 2. Percentage of bud break of all grafting treatments two month after cutting (MAC)

\begin{tabular}{|c|c|c|c|c|c|}
\hline $\begin{array}{l}\text { Perlakuan } \\
\text { Treatment }\end{array}$ & $\begin{array}{l}\text { Jumlah } \\
\text { awal stek } \\
\text { Initial } \\
\text { Amount of } \\
\text { cutting }\end{array}$ & $\begin{array}{c}\text { Stek mati } \\
\text { Dead of } \\
\text { cutting }\end{array}$ & $\begin{array}{l}\text { Stek hidup namun } \\
\text { belum pecah tunas } \\
\text { Cutting survive but } \\
\text { hasn't break }\end{array}$ & $\begin{array}{l}\text { Stek hidup } \\
\text { dan pecah } \\
\text { tunas } \\
\text { Cutting } \\
\text { survive and } \\
\text { break }\end{array}$ & $\begin{array}{c}\text { Persentase } \\
\text { terhadap stek } \\
\text { awal } \\
\text { Percentage } \\
\text { compare on } \\
\text { initial amount } \\
\text { of cutting } \\
(\%) \\
\end{array}$ \\
\hline $\begin{array}{l}\text { Okulasi } \\
\text { pertama } \\
\text { (kontrol) }\end{array}$ & 38 & 5 & 3 & 30 & 78,9 \\
\hline Okulasi kedua & 36 & 9 & 6 & 21 & 58,3 \\
\hline Okulasi ketiga & 32 & 8 & 5 & 19 & 59,4 \\
\hline Jumlah Total & 106 & $22(20,7 \%)$ & $14(13,2 \%)$ & $70(66,0 \%)$ & \\
\hline
\end{tabular}

\section{Waktu dan Jumlah Pecah Tunas}

Waktu rata-rata tanaman mulai pecah tunas adalah 7 Hari Setelah Stek (HSS) dengan jumlah rerata 2,67 tanaman per perlakuan (Gambar 2). Waktu rata-rata optimal pecah tunas untuk setiap perlakuan terjadi pada kisaran 11 - 19 HSS. Rata-rata pecah tunas untuk setiap perlakuan mencapai jumlah tertinggi pada 15 HSS. Jumlah pecah tunas paling banyak terjadi pada hari ke-15 untuk perlakuan okulasi pertama (kontrol), adapun pada okulasi kedua pada hari ke-19, dan perlakuan okulasi ketiga terjadi pada hari ke-11. Kisaran waktu tersebut masih dianggap rentang waktu normal pecah tunas bibit okulasi karet. 


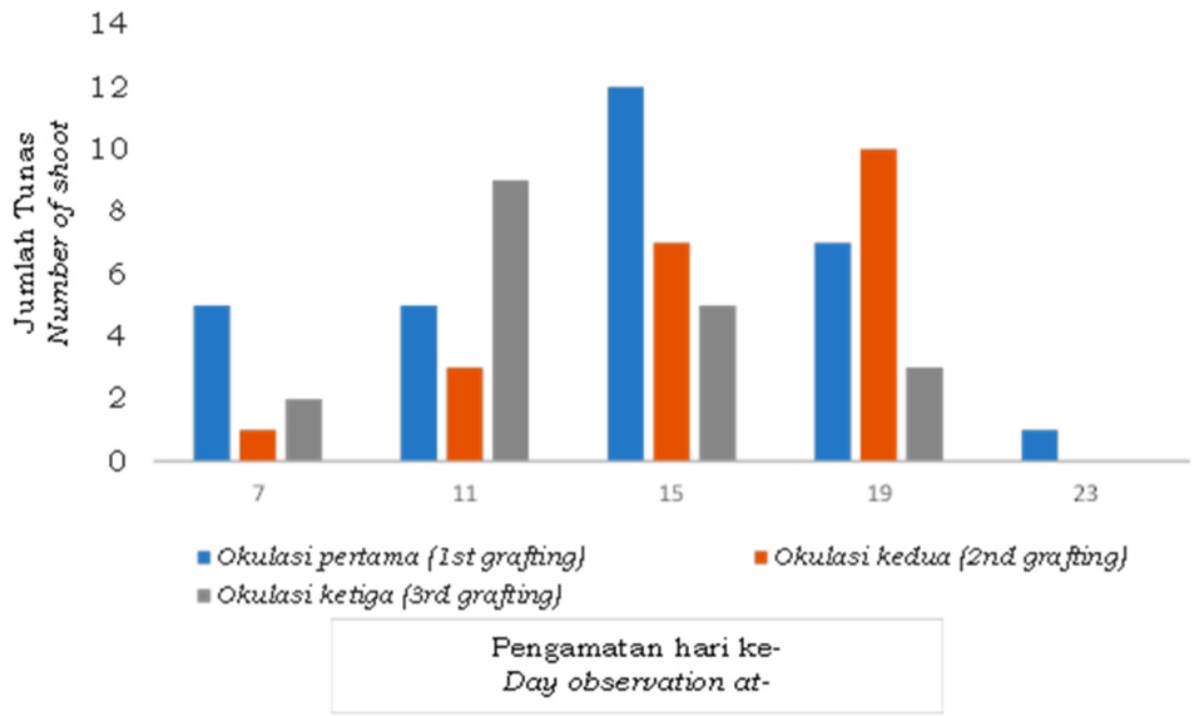

Gambar 2. Sebaran jumlah pecah tunas dari pengamatan hari ke-7 hingga ke-23 Figure 2. A distribution of a number of bud break from $7^{\text {th }}$ to $23^{\text {rd }}$ days of observation

Keragaman kisaran waktu pecahnya tunas diduga karena pengaruh perbedaan kondisi batang bawah, baik diameter, tebal kulit maupun kondisi nutrisi. Syukur (2012) dalam hasil penelitiannya pada bibit karet menyatakan bahwa pemecahan mata tunas rata-rata terjadi pada kisaran umur 10 hingga 40 hari setelah pindah tanam. Hal tersebut dipengaruhi oleh klon yang digunakan sebagai batang atas dan proses metabolisme dalam tanaman yang berpengaruh terhadap laju kecepatan pecahnya mata tunas. Status hara dan karbohidrat pada batang bawah yang digunakan untuk stek juga mempengaruhi kecepatan munculnya tunas dan proses pertumbuhan selanjutnya. Bartolini et al. (1996) menyatakan bahwa kandungan nutrisi, pati, dan $\mathrm{CHO}$ terlarut pada tanaman merupakan stimulator utama dalam inisiasi pertumbuhan meristem. Proliferasi sel dapat diinisiasi ketika tersedia $\mathrm{CHO}$ yang cukup untuk mendukung nutrisi bagi pembelahan sel. Sitokinin, sukrosa, dan glukosa akan menstimulasi proliferasi sel dan memicu ketersediaan nutrisi pada lubuk (sink), yang selanjutnya mendorong pertumbuhan dan diferensiasi jaringan tanaman. Seleksi batang bawah yang akan digunakan untuk stek penting dilakukan, di samping menyiapkan dengan pemeliharaan yang optimal untuk mendukung hasil stek yang lebih baik.

\section{Pertumbuhan Tunas Pasca Stek}

Hingga umur 49 HSS tinggi tunas hasil stek ruas okulasi kedua $(8,17 \mathrm{~cm})$ dan ketiga $(7,36 \mathrm{~cm})$ tidak berbeda nyata namun keduanya nyata lebih rendah dibandingkan kontrol $(18,05 \mathrm{~cm})$. Laju pertumbuhan tunas pada pengamatan hari ke-21 hingga hari ke49 juga tidak secepat pada tanaman kontrol (Gambar 3). Kecepatan tumbuh pada tanaman kontrol lebih tinggi karena kondisi perakaran yang lebih baik. Tanaman kontrol memiliki perakaran yang lebih baik dan sudah mapan karena masih menyertakan sebagian akar tunggang saat pindah root trainer.

Kondisi perakaran yang lebih baik pada perlakuan kontrol mendukung suplai nutrisi untuk pertumbuhan tunas sehingga laju pertumbuhan tunas lebih cepat. Tanaman akhirnya segera mampu melakukan fotosintesis sendiri dan mentransfer asimilat dengan lebih cepat. Stek yang tidak mampu memicu pertumbuhan akar selanjutnya tidak mampu menunjukkan perkembangan tunas dan akhirnya mengalami kematian. Perbedaan kondisi tunas dan perakaran diantara perlakuan okulasi pertama, kedua, dan ketiga dapat dilihat pada Gambar 4. 


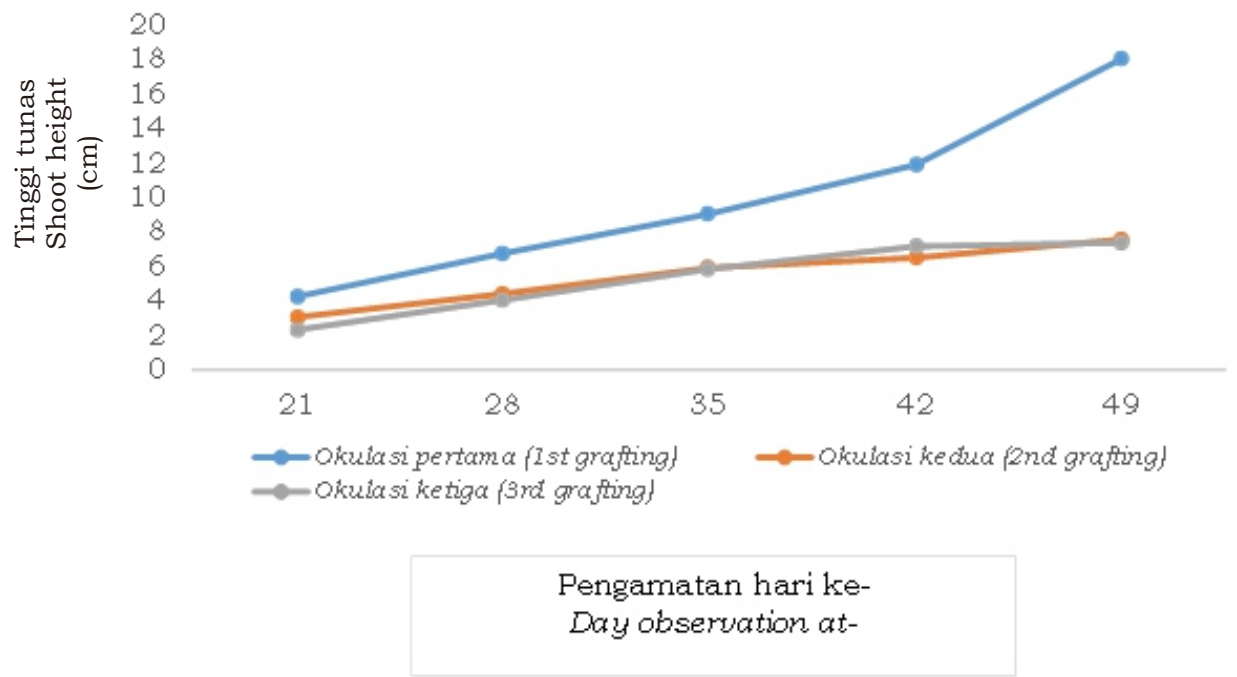

Gambar 3. Laju pertumbuhan tunas okulasi dari hari ke-21 hingga ke-49

Figure 3. A growth rate of shoot from $21^{\text {st }}$ to $49^{\text {th }}$ day of observation

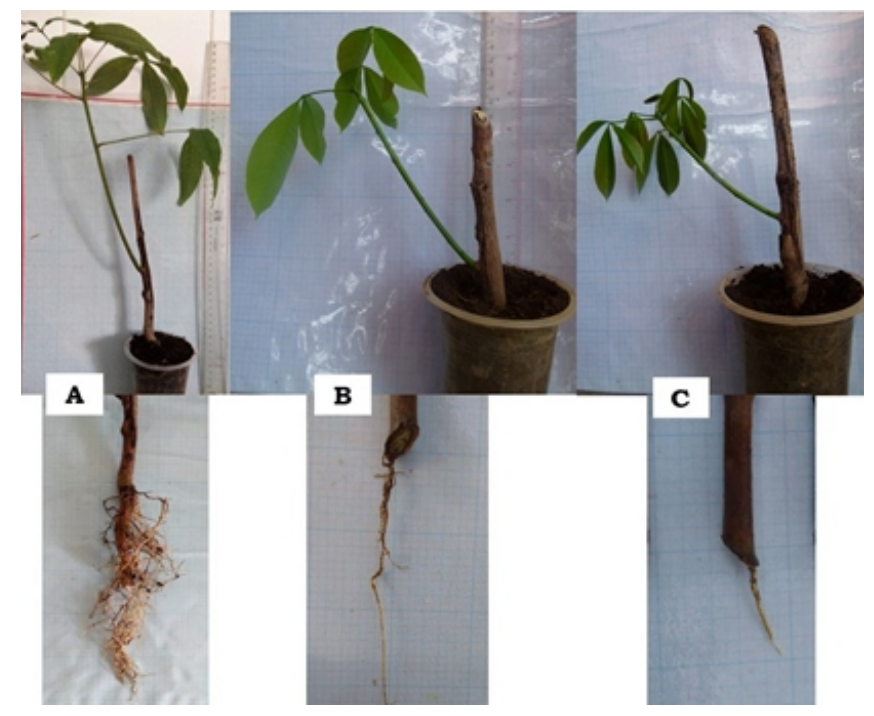

Gambar 4. Perbedaan tunas dan perakaran pada okulasi pertama (A), okulasi kedua (B), dan okulasi ketiga (C) pada pengamatan hari ke-49.

Figure 4. Shoot and rooting differences on $1^{\text {st }}(A), 2^{\text {nd }}(B)$, and $3^{\text {rd }}(C)$ grafting on $49^{\text {th }}$ day of observation.

Pertumbuhan tunas pada stek batang yang belum memiliki perakaran normal didukung oleh cadangan karbohidrat pada batang. Pada fase awal kemunculan hingga pecahnya tunas yang kemudian diikuti oleh pertumbuhan tunas sangat didukung oleh karbohidrat yang tersimpan pada jaringan tanaman (Zhao et al., 2014). Kondisi perakaran yang belum terinduksi menyebabkan pertumbuhan tunas akhirnya terhenti bahkan gagal dan mengalami kematian. Hal ini terjadi karena pertumbuhan tunas hanya mengandalkan cadangan makanan pada batang, sehingga ketika cadangan makanan tidak lagi mencukupi dan akar belum siap untuk menyerap air dan mineral, maka tanaman akan mengalami kematian. Kondisi ini sesuai dengan pendapat Hartman dan Kester (1975) yang menyatakan bahwa kematian yang tinggi mungkin terjadi pada stek berdiameter kecil sebelum sempat 
membentuk akar. Svenson et al. (1995) dalam Peter (2010) menyatakan, setelah dipisahkan dari tanaman induk stek dapat melanjutkan proses fotosintesis, namun karena hanya berupa batang, stek akan mengurangi transpirasi, dan net fotosintesis.

\section{Respon Perakaran}

Respon perakaran stek ruas okulasi kedua dan ketiga masih nyata lebih rendah jika dibandingkan dengan kontrol, yaitu masing-masing hanya sekitar $69 \%$ dan $52 \%$ (Gambar 5). Stek ruas okulasi kedua menunjukkan hasil yang nyata berbeda daripada stek ruas okulasi ketiga, baik pada persentase berakar maupun panjang akar.
Perbedaan diameter dan posisi batang diduga berpengaruh terhadap respon perakaran. Ruas okulasi kedua memiliki diameter batang yang lebih besar dibandingkan ruas okulasi ketiga, di samping posisi okulasi kedua yang mendekati pangkal batang (bagian bawah) dibandingkan posisi okulasi ketiga yang lebih di atas. Corpuz (2013) juga mendapatkan hasil senada pada stek batang bawah karet, dimana pada batang bawah berwarna cokelat menghasilkan panjang akar yang signifikan lebih baik dibandingkan pada asal stek batang hijau atau peralihan hijau-cokelat $(6,67 \mathrm{~cm}$ berbanding $4,65 \mathrm{~cm}$ ).

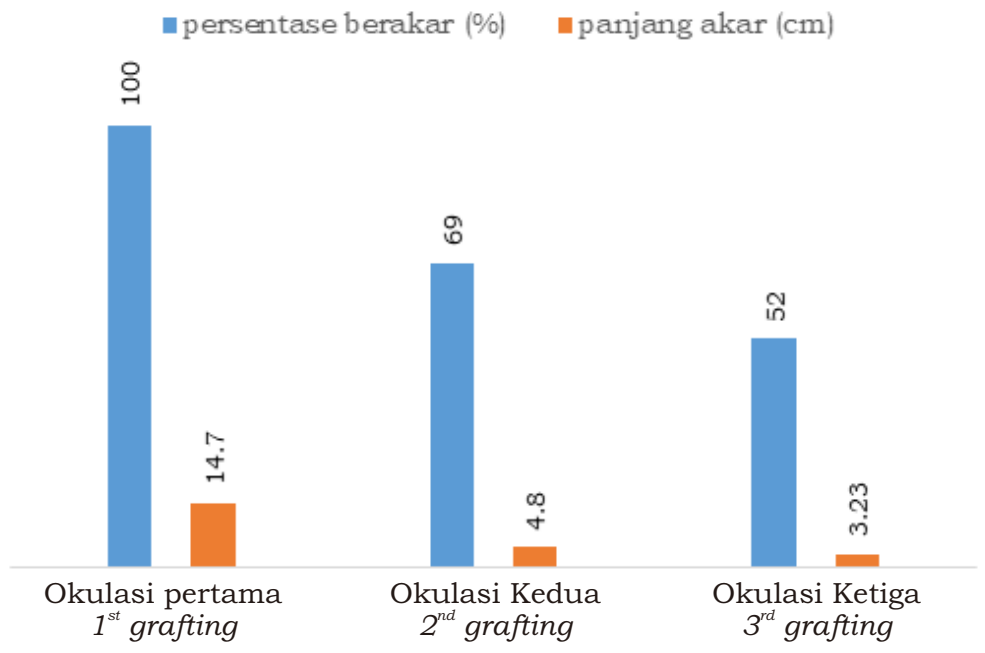

Gambar 5. Perbandingan persentase berakar dan panjang akar antar semua perlakuan okulasi.

Figure 5. Comparation of percentage of rooting and root length between all grafting treatments.

Huat dan Kazemaian (2010) menyatakan bahwa kemampuan berakar stek batang tanaman kayu juga bergantung pada fase pertumbuhan tanaman donor dan posisi saat batang stek diambil. Desrochers dan Thomas (2003) dalam Zhao et al. (2014) menyebutkan bahwa batang stek pada tanaman poplar yang diambil pada posisi bagian bawah menghasilkan perakaran yang lebih panjang dan lebih banyak dibandingkan dengan posisi batang bagian atas, di samping ukuran diameter juga mempengaruhi kemampuan berakar. Stek pada tanaman Peltophorum pterocarpum juga menunjukkan respon pertumbuhan dan biomassa akar yang lebih baik jika diambil pada posisi basal dibandingkan pada posisi bagian atas (Saifudin et al., 2013).

Frey et al. (2003) dalam Zhao et al. (2014) menyebutkan bahwa ukuran diameter stek yang lebih besar akan memiliki kemampuan berakar yang lebih baik karena memiliki cadangan karbohidrat, fotosintat, dan hormon atau promotor akar endogen yang lebih banyak. Peran intensitas cahaya dan adanya ketersediaan asupan karbohidrat juga mendukung respon kemunculan akar adventif pada tanaman Eucalyptus globulus (sulit berakar) dan Eucalyptus saligna (mudah berakar) yang diuji (da Rocha Corre`a et al., 2005). 
Kandungan hormon dan nutrisi tanaman asal stek juga mempengaruhi perkembangan akar. Pada penelitian ini perlakuan menggunakan zat pengatur tumbuh komersial berbahan aktif NAA dan IBA dengan konsentrasi sesuai dosis yaitu 5 g/L. Stek tanaman karet yang diberi perlakuan NAA dengan konsentrasi $15 \mathrm{~g} / \mathrm{L}$ menghasilkan jumlah dan panjang akar terbaik yaitu $6,167 \mathrm{~cm}$ dan $6 \mathrm{~cm}$ (AntwiWiredu et al., 2018). Stek pada tanaman eukaliptus yang diberi perlakuan auksin pada tunasnya mampu membentuk akar adventif pada banyak bagian di sepanjang jaringan vaskuler yang melingkar (Bryant \& Trueman, 2015). Domenicano et al. (2011) melaporkan bahwa kandungan nitrogen mempengaruhi perkembangan akar pada stek tanaman poplar, yaitu rasio akar serabut yang lebih besar dan panjang akar yang signifikan.

\section{Berat Basah dan Berat Kering Akar Maupun Tunas}

Total berat basah dan berat kering batang dan tunas pada perlakuan okulasi kedua dan okulasi ketiga tidak berbeda nyata, hanya peubah berat basah dan berat kering akar yang menunjukkan perlakuan okulasi kedua lebih baik dibandingkan okulasi ketiga. Keduanya nyata lebih rendah untuk seluruh peubah jika dibandingkan dengan kontrol okulasi pertama (Tabel 3). Hasil ini sejalan dengan hasil persentase berakar dan panjang akar pada pembahasan sebelumnya, di mana okulasi kedua menunjukkan hasil yang lebih baik dibandingkan pada okulasi ketiga, sekalipun belum mampu melampaui kontrol. Rasio berat kering akar dan tunas pada stek okulasi kedua dan ketiga lebih rendah dibandingkan kontrol. Hasilnya

Tabel 3. Rata-rata berat basah dan berat kering tunas dan akar pada perlakuan okulasi yang berbeda.

Table 3. Average of dry and fresh weight of shoot and root on each grafting treatments.

\begin{tabular}{|c|c|c|c|}
\hline $\begin{array}{l}\text { Variabel } \\
\text { Variables }\end{array}$ & $\begin{array}{c}\text { Okulasi pertama } \\
\text { (kontrol) } \\
1^{\text {st }} \text { grafting } \\
\text { (control) }\end{array}$ & $\begin{array}{c}\text { Okulasi } \\
\text { kedua } \\
2^{\text {nd }} \text { grafting }\end{array}$ & $\begin{array}{l}\text { Okulasi ketiga } \\
3^{r d} \text { grafting }\end{array}$ \\
\hline \multicolumn{4}{|l|}{ Berat basah } \\
\hline Berat basah batang (g) & $26,74^{\mathrm{a}}$ & $15,08^{b}$ & $13,41^{b}$ \\
\hline Berat basah tunas (g) & $9,27^{\mathrm{a}}$ & $2,58^{b}$ & $2,13^{b}$ \\
\hline Berat basah akar (g) & $12,23^{a}$ & $2,05^{b}$ & $1,85^{\mathrm{ab}}$ \\
\hline Berat basah total (g) & $48,24^{a}$ & $19.71^{\mathrm{b}}$ & $17.39 \mathrm{~b}$ \\
\hline \multicolumn{4}{|l|}{ Berat kering } \\
\hline Berat kering batang (g) & $13,72^{\mathrm{a}}$ & $9,87^{b}$ & $9,45^{b}$ \\
\hline Berat kering tunas (g) & $4,04^{a}$ & $1,23^{b}$ & $1,02^{b}$ \\
\hline Berat kering akar (g) & $7,67^{a}$ & $0,85^{b}$ & $0,54^{\mathrm{ab}}$ \\
\hline Berat kering total (g) & $25,43^{a}$ & $10,39 b$ & $9,81^{\mathrm{b}}$ \\
\hline $\begin{array}{l}\text { Rasio berat kering } \\
\text { akar : tunas }\end{array}$ & 1,89 & 0,69 & 0,52 \\
\hline
\end{tabular}

Keterangan (Remaks):

Angka yang diikuti dengan huruf yang sama pada baris yang sama menunjukkan tidak berbeda nyata pada taraf signifikasi $5 \%$ berdasarkan uji Tukey. (Number followed by the same letter at the same row were not significantly different at $5 \%$ based on Tukey test). 
masing-masing berturut-turut sebesar 0,69 dan 0,52 berbanding 1,89. Rasio tersebut mencerminkan keseimbangan antara akar dan tunas pada tanaman hasil stek.

Keseimbangan akar dan tunas merupakan salah satu indikator kemampuan adaptasi bahan tanam pada kondisi pertumbuhan yang optimal saat dipindah tanam di lapangan. Pada tanaman karet, diketahui rasio akar dan tunas yang kurang dari 0,5 mengindikasikan kondisi tanaman masih rentan untuk dipindah tanam ke lapangan (Othman et al., 1991). Rasio akar dan tunas pada stek setelah okulasi dengan nilai tersebut masih dianggap rawan dan masih perlu upaya peningkatan melalui berbagai perlakuan stimulasi akar yang lebih baik.

Beberapa faktor yang dapat mempengaruhi rasio berat akar dan tunas (root shoot ratio) antara lain umur tanaman, kerapatan jarak tanam, media tanam, kesuburan tanah, asosiasi dengan mikoriza, volume akar dan pemotongan akar (Poorter et al., 2012). Keragaman seedling monoklonal dan teknik perbanyakan yang berbeda juga akan mempengaruhi rasio akar dan tunas pada tanaman karet (Othman et al., 1991). Pengaruh ukuran panjang maupun diameter stek tanaman jarak pagar memiliki pola yang serupa, yaitu lebih banyak berpengaruh nyata terhadap komponen tajuk dibandingkan komponen akar (Santoso et al., 2008). Posisi batang stek bagian bawah (basal position) memiliki aktivitas fisiologi yang lebih tinggi dibandingkan pada posisi bagian atas (apical position), mungkin inilah yang menyebabkan potensi berakar pada batang bagian bawah lebih besar seperti yang dinyatakan oleh AlSalem dan Karam (2001) dalam Saifudin et al. (2013), sehingga rasio akar: tunas lebih tinggi pada okulasi pertama, menyusul okulasi kedua dan okulasi ketiga. Peningkatan laju fotosintesis mungkin berhubungan dengan keberadaan kandungan karbohidrat pada batang dan kapasitas penyerapan air melalui perakaran yang terinduksi (Ezekiel, 2010).

Optimasi kondisi perakaran pada perbanyakan stek harus diupayakan, karena membuka peluang sistem perbanyakan karet dengan teknik stek ruas batang bawah terokulasi, dan dapat mengatasi persoalan ketersediaan sumber biji. Tan (1995) menyatakan tidak ada indikasi bahwa perbanyakan tanaman karet dengan stek memiliki perbedaan yang superior dari okulasi dari sisi performa hasil dan lilit batang.

\section{KESIMPULAN}

Tingkat keberhasilan okulasi pertama (kontrol) sebesar 84\%, okulasi kedua sebesar $80 \%$, dan okulasi ketiga lebih rendah yaitu $71 \%$. Waktu optimal pecah tunas yaitu 11-19 HSS. Rata-rata tinggi tunas stek okulasi kedua dan ketiga pada umur 49 HSS mencapai 7,55 $\mathrm{cm}$ dan 7,66 $\mathrm{cm}$, dan persentase berakar masing-masing $69 \%$ dan $52 \%$, dengan rata-rata panjang akar 4,80 cm dan 3,23 cm. Keduanya nyata lebih rendah dibanding kontrol. Stek batang bawah ruas okulasi kedua berpotensi untuk mendukung perbanyakan bibit klonal, namun perlu dilakukan optimasi induksi dan pertumbuhan perakaran yang mendekati pertumbuhan bibit konvensional.

\section{DAFTAR PUSTAKA}

Antwi-Wiredu, A., Amiteye, S., Diawuoh, R.G., \& Klu, G.Y.P. (2018). Ex Vitro propagation of rubber tree (Hevea brasiliensis) using stem cuttings. International Journal of Environment, Agriculture and Biotechnology, 3(3), 846-854. Doi: 10.22161/ijeab/3.3.20

Baron, D., Amaro, A.C.E., Pina, A., \& Ferreira, G. (2019). An overview of grafting re-establishment in woody fruit species. Scientia Horticulturae, $243, \quad 84-91 . \quad$ D o i : 10.1016/j.scienta.2018.08.012.

Bartolini, G., Pestelli, P., Toponi, M.A., \& Di Monte, G. (1996). Rooting and carbohydrate availability in Vitis 140 Ruggeri stem cuttings. VitisGeilweilerhof, 35(1), 11-14.

Baulkwill, W.J., \& Webster, C.C. (1989). Rubber. New York, USA: John Wiley \& Sons Inc. 
Bryant, P.H., \& Trueman, S.J. (2015). Stem anatomy and adventitious root formation in cuttings of Angophora, Corymbia and Eucalyptus. Forests, 6 (4), $1227-1238$. D o i : $10.3390 /$ f6041227.

Corpuz, O.S. (2013). Stem cut: An alternative propagation technology for rubber (Hevea brasiliensis) tree species. International Journal of Biodiversity and Conservation, 5(2), 78-87. Doi: 10.5897/IJBC12.122.

Da Rocha Corre^a, L., Paim, D.C., Schwambach, J., \& Fett-Neto, A.G. (2005). Carbohydrates as regulatory factors on the rooting of Eucalyptus saligna Smith and Eucalyptus globulus Labill. Plant Growth Regulation, 45(1), 63-73. Doi: 10.1007/s10725-0046125-z.

De Almeida, M.R., Aumond Jr, M., Da Costa, C.T., Schwambach, J., Ruedell, C.M., Correa, L.R., \& Fett-Neto, A.G. (2017). Environmental control of adventitious rooting in Eucalyptus and Populus cuttings. Trees, 31(5), 1377-1390. Doi: 10.1007/s00468-017-1550-6.

Domenicano, S., Coll, L., Messier, C., \& Berninger, F. (2011). Nitrogen forms affect root structure and water uptake in the hybrid poplar. New Forests, 42(3), 347-362. Doi: 10.1007/s 11056011-9256-x.

Ezekiel, A. (2010). Viable options and factors in consideration for low cost vegetative propagation of tropical trees. International Journal of Botany, 6(2), $187-193$. D o i : 10.3923/ijb.2010.187.193.

Hartmann, H.T., Kester, D.E., Driver, F.T., \& Geneve, R.L. (1975). Plant propagation: principles and practices. New Jersey, USA: Prentice-Hall.

Howard, Y. (1996). Relationships between shoot growth and rooting of cuttings in three contrasting species of ornamental shrub. Journal of Horticultural Science, 71(4), 591-605. Doi:10.1080/14620316.1996.115154 39.
Huat, B.B.K., \& Kazemian, S. (2010). Study of root theories in green tropical slope stability. Electronic Journal of Geotechnical Engineering., 15, 1825-1834

Othman, H., Leong, S.K., \& Samsuddin, Z. (1991). Root-shoot balance of Hevea planting materials. Developments in Agricultural and Managed Forest Ecology, 24, 248-256. Doi: $10.1016 /$ B $978-0-444-89104$ 4.50037-2.

Owen Jr, J.S., \& Maynard, B.K. (2007). Environmental effects on stem-cutting propagation: a brief review. Combined Proceedings International Plant Propagators' Society, 57, 558-564).

Peter, A. (2010). Unrooted stem cutting physiology; water use and leaf gas exchange of severed stem cuttings. (Theses), Graduate School of Clemson University, USA.

Poorter, H., Bühler, J., van Dusschoten, D., Climent, J., \& Postma, J.A. (2012). Pot size matters: a meta-analysis of the effects of rooting volume on plant growth. Functional Plant Biology, 39, 839-850. Doi: 10.1071/FP12049

Saifuddin, M., Osman, N., \& Rahman, M.M. (2013). Influence of different cutting positions and rooting hormones on root initiation and root-soil matrix of two tree species. International Journal of Agriculture and Biology, 15(3), 427-434.

Santoso, B.B., Hasnam, Hariyadi, Susanto, S., \& Purwoko, B.S. (2008). Perbanyakan vegetatif tanaman jarak pagar (Jatropha curcas L.) dengan stek batang: pengaruh panjang dan diameter stek. Buletin Agronomi, 36(3), $255-262 . \quad \mathrm{D}$ o i : 10.24831/jai.v36i3.1385

Syukur. (2012). Kajian okulasi benih karet (Hevea brasiliensis Muell. Arg) dengan perbedaan mata tunas (entres) dan klon, (Tesis), Universitas Sebelas Maret, Indonesia. 
Tan, H. (1995). Variability of cuttings and buddings in three hevea cultivars. Journal of Natural Rubber Research, 10(3), 209-217.
Zhao, X., Zheng, H., Li, S., Yang, C., Jiang, J., $\&$ Liu, G. (2014). The rooting of poplar cuttings: a review. New Forests, 45, 21-34. Doi: $10.1007 / \mathrm{s} 11056-013-$ 9389-1 